日作紀（Jpn. J. Crop Sci.）86（4）：319-328（2017）

\title{
パン用コムギ品種「ミナミノカオリ」における穂肥重点施肥が 収量や子実タンパク質含有率におよぼす影響
}

\author{
水田圭祐 ${ }^{1)} \cdot$ 荒木英樹 $^{1)} \cdot$ 中村和弘 ${ }^{2)} \cdot$ 松中仁 ${ }^{2)} \cdot$ 丹野研一 ${ }^{1)} \cdot$ 高橋肇 $^{1)}$ \\ (1) 山口大学大学院創成科学研究科, ${ }^{2}$ 農研機構九州沖縄農業研究センター)
}

\begin{abstract}
要旨：暖地向けパン用コムギ品種「ミナミノカオリ」は, 子実タンパク質含有率が高いものの, 収量が低いという特 徵がある. 本研究では, 熊本県のコムギ多収地域において,「ミナミノカオリ」の高品質多収化を目的として, 基肥 と分げつ肥を省略し, 穂肥を増肥した穂肥重点施肥が, 収量, 収量構成要素, 分げつの成長量や消長におよぼす影響 を検証した，穂肥重点施肥区は，2014/15 年と 2015/16 年のいずれも慣行分施区に比べて穂数が 5 20\%増加した. その結果，2014/15 年では慣行分施区に比べて収量が 15\%増加した，子実タンパク質含有率は，収量が増加したにも かかわらず低下しなかった，2015/16 年では，収量は $607 \mathrm{~g} \mathrm{~m}^{-2}$ と慣行分施区と同程度であったが，子実タンパク質含 有率は $13.8 \%$ と慣行分施区の $12.5 \%$ に比べて有意に高くなった。一穂粒数と千粒重はいずれの作期でも穂肥重点施 肥では増加しなかった，穂肥重点施肥区で穂数が増加した原因は，主茎第 3 節分げつの有効化した茎の発生率が $62.2 \%$ と, 慣行分施区の $19.1 \%$ に比べて高いためであった，成熟期における主茎第 3 節分げつの乾物重は, 穂肥重 点施肥区で $2.28 \mathrm{~g}$ と慣行分施区の $1.67 \mathrm{~g}$ に比べて有意に重かった，地上部窒素蓄積量は, 慣行分施区では穂揃い期 から成熟期にかけて $3.6 \mathrm{~g} \mathrm{~m}^{-2}$ 増加し, 穂肥重点施肥区では $5.3 \mathrm{~g} \mathrm{~m}^{-2}$ 増加した. その結果, 成熟期では, 穂肥重点施 肥区で $18.8 \mathrm{~g} \mathrm{~m}^{-2}$ と慣行分施区の $15.6 \mathrm{~g} \mathrm{~m}^{-2}$ に比べて有意に多かった。穂肥重点施肥は, 収量が増加しても窒素吸収 量を増加させることで子実夕ンパク質含有率を高水準に維持するため, パン用コムギの高品質多収栽培に有効である と考えられた。
\end{abstract}

キーワード:子実タンパク質含有率, 多収, 窒素蓄積量, パン用コムギ品種, 分げつ, 穂肥重点施肥, ミナミノカオリ.

パン用・中華麺用コムギは, 山口・九州地域の麦作の中 でも生産量が拡大している. 麦類の検査数量（農林水産省 2017a）によれば, 山口県抢よび九州各県のパン用・中華 麺用品種（「さちかおり」,「せときらら」,「ちくしW2 号」, 「長崎 W2 号」,「ニシノカオリ」, 「ミナミノカオリ」) の総 検査数量は, 平成 19 年 (2007 年) 産で 8845 トンであった のに対し, 平成 26 年（2014 年）産では 21974 トンにまで 増加している。

パン用コムギ品種「ミナミノカオリ」は熊本県, 大分県, 福岡県, 長崎県の奨励品種となっており, 九州でのパン用 コムギの最も重要な品種となっている。「ミナミノカオリ」 は程長と穂長が短いため耐倒伏性が強く, パンの比容積 (ふ くらみ）や官能試験の評定が良く製パン適正が優れるもの の，穂数がやや少ないため収量もやや低いという特徴があ る(藤田ら 2009). 熊本県の場合, 「ミナミノカオリ」を含 むコムギの収量は, 平成 19 年から平成 26 年間の平均収量 が $31.7 \mathrm{~kg} \mathrm{a}^{-1}$ と普通小麦の全国平均収量の $37.6 \mathrm{~kg} \mathrm{a}^{-1}$ に 比べて低く, 同県の多収地域である大津町に限っても $38.2 \mathrm{~kg} \mathrm{a}^{-1}$ にとどまる(農林水産省作物統計の作況調査「市 町村別デー夕」からの計算值).

パン用コムギでは品質，とくに子実タンパク質含有率が 重要視される。 パン用コムギのランク区分では，子実タン パク質含有率の基準值が $11.5 \sim 14.0 \%$ と設定されている. 製パン性の指標となるパン比容積は, 製粉した $60 \%$ 粉の
粗タンパク質含有率が $12 \%$ までの範囲では, 粗タンパク 質含有率が増加するにしたがって増加する（佐藤ら 1999）。 コムギの子実タンパク質含有率は，収量が増加するにした がって低下しやすくなる（江口ら 1969, 岩渕ら 2011, Hitz ら 2017)。そのため, パン用コムギ品種の多収栽培では, 収量を高めつつ子実タンパク質含有率を低下させない栽培 方法が必要となる。

コムギの子実タンパク質含有率は, 施肥方法や地力を改善 することで高まることが知られている. 子実タンパク質含有 率は, 出穂 10 日後に窒素を追肥すること（高山ら 2004), 開 花期以降に窒素を追肥することで増加すること（岩渕ら 2007，佐藤ら 2009，島崎ら 2014）が報告されている。島 崎ら（2015）は, 畑では水田に比べて穂の開花前窒素蓄積 量が多いことによって成熟期の穂の窒素蓄積量が多かった と報告している. Hitz ら（2017）は, 開花期の窒素蓄積量 と成熟期の子実窒素含有量の間に正の相関関係があること を報告している，そのため，子実タンパク質含有率を高め るには，出穂期以降の窒素追肥量を増やすだけでなく，開 花前の窒素蓄積量を高められるように施肥方法を考える必 要がある.

コムギでは，生育後半に窒素を重点的に追肥する施肥方 法により収量を高めることが報告されている，日本のコム ギ栽培では, 茎数を増やすために基肥や分げつ肥を施用す る（和田 2002）が，海外に扔けるコムギ栽培では，基肥と

2017 年 5 月 8 日受理。連絡責任者：荒木英樹 $\bar{\top} 753-8515$ 山口県山口市吉田 1677-1

TEL 083-933-5920, FAX 083-933-5920, ahide@yamaguchi-u.ac.jp 
第 1 表 $2014 / 15$ 年作期の試験戋場における作土の理化学性

\begin{tabular}{cccccc}
\hline $\mathrm{pH}$ & 全窒素 & 可給態リン酸 & \multicolumn{3}{c}{ 交換性塩基 $\left(\mathrm{g} \mathrm{kg}^{-1}\right.$ 乾土 $)$} \\
\cline { 4 - 6 }$\left(\mathrm{H}_{2} \mathrm{O}\right)$ & $\left(\mathrm{g} \mathrm{kg}^{-1}\right.$ 乾土 $)$ & $\left(\mathrm{g} \mathrm{kg}^{-1}\right.$ 乾土 $)$ & $\mathrm{K}_{2} \mathrm{O}$ & $\mathrm{CaO}$ & $\mathrm{MgO}$ \\
\hline 5.00 & 3.26 & 0.27 & 0.36 & 6.02 & 0.45 \\
\hline
\end{tabular}

測定は, 表土から $10 \mathrm{~cm}$ 深までの作土を対象に行った。

して窒素を施用せず，追肥中心の施肥体系が多い，関根・ 梅本（2015）は，ドイッでは農業コンサルタントの指導に 基づき基肥は施用して抢らず，追肥のみであることを報告 している，イギリスの農業コンサルタント（AHDB）の冬 コムギ経営指針においても，穂肥時期の追肥が中心の施肥 体系が推奨されている (AHDB 2009)。浦野・保科 (2012) や浦野（2014）は，コムギやオオムギにおいて，基肥に速 効性の窒素肥料を施用せず，窒素肥料として被覆尿素のみ を全量基肥に施用した場合や，硫安を穂肥にのみ施用した 場合でも，収量が慣行施肥以上となることを報告している. 渡邊ら（2016）は，多収品種「さとのそら」を用い，基肥 を抑えて分げつ肥や荃立ち期の窒素施用量を増肥すること によって，乳熟期以降の乾物生産が増加することで収量が 15〜 50\%増加し，なおかつ子実タンパク質含有率が低下し ないことを報告している。

一方，茎立ち開始期以降に窒素を多く追肥することで生 じる問題点も指摘されている。これまでの研究では，茎立 ち期前から茥立ち期にかけて窒素を増肥すると，稈長が伸 び倒伏しやすくなることや，茥立ち以降の窒素追肥や穂肥 の増肥によって遅れ穂が増加することが報告されている（江 口ら 1969, 倉井ら 1998, 竹内ら 2006, 土谷 2012). しかし, いずれの試験も生育期間中の窒素施用が基肥と分げつ肥で 多い体系を基本としていることから，基肥や分げつ肥で窒 素施用量を抑えた条件では異なる結果となる可能性もある.

本研究では，パン用コムギ品種「ミナミノカオリ」の多 収地域である熊本県菊池郡大津町において，基肥と分げつ 肥を省略し，その分穂肥を増肥する穂肥重点施肥が，「ミ ナミノカオリ」の収量水準を高められるかどうか，増収に より予見される子実タンパク質含有率の低下が生じるかど うかを検証した，収量は，生育後期重点施肥では穂数が増 加することで増加したことが報告されている（渡邊ら 2016）ことから，主菱や分げつの成長量や消長を発生節位 別に解析した。 また，穂肥窒素を増肥することで予見され る倒伏や遅れ穂の発生についても解析した。

\section{材料と方法}

試験は, $2014 / 15$ 年と 2015/16 年の 2 作期にわたり，熊 本県菊池郡大津町 (北緯 32 度 51 分, 東経 130 度 52 分) の農家围場で栽培されたパン用コムギ品種「ミナミノカオ リ」を対象に行った。戋場は，いずれの年次も夏作として ダイズを栽培したあと地であった。土壤は，黒ボク土に分 類され，理化学性は第 1 表に示した，理化学性分析に供試
第 2 表 $2014 / 15$ 年および 2015/16 年作期における窒素肥料の施肥 時期と施用量

\begin{tabular}{|c|c|c|c|c|c|}
\hline \multirow[b]{2}{*}{ 処理区 } & \multicolumn{5}{|c|}{ 施肥時期 $\left(\mathrm{g} \mathrm{m}^{-2}\right)$} \\
\hline & 基肥 & $\begin{array}{c}\text { 分げつ肥 } \\
(\mathrm{GS} 14)\end{array}$ & $\begin{array}{l}\text { 穂肥 I } \\
\text { (GS30) }\end{array}$ & $\begin{array}{c}\text { 穂肥 } \\
\text { (GS32) }\end{array}$ & $\begin{array}{l}\text { 穂肥 II } \\
\text { (GS47) }\end{array}$ \\
\hline \multicolumn{6}{|l|}{$2014 / 15$ 年 } \\
\hline 慣行分施区 & 5.5 & 3.0 & & 2.0 & \\
\hline 慣行基肥 2 倍区 & 11.0 & 3.0 & & 2.0 & \\
\hline 穂肥重点施肥区 & & & 5.0 & & 5.0 \\
\hline 穂肥重点 2 倍区 & & & 5.0 & & 10.0 \\
\hline \multicolumn{6}{|l|}{$2015 / 16$ 年 } \\
\hline 慣行分施区 & 4.0 & 3.0 & & 3.0 & \\
\hline 穂肥重点施肥区 & & & 5.0 & & 5.0 \\
\hline 穂肥重点多肥区 & & & 5.0 & 9.4 & 5.0 \\
\hline
\end{tabular}

GS は, Zadoks ら (1974) の生育ステージを示す.

した土壤サンプルは，2014 年 12 月 8 日に基肥を施用する 前に地表下 $10 \mathrm{~cm}$ 深の作土を移植ごてで採取した.

播種は, $2014 / 15$ 年では 12 月 8 日，2015/16 年では 12 月 1 日に行った。播種量は，両作期とも全ての処理区で約 $7 \mathrm{~g} \mathrm{~m}^{-2}$ とした。条間は $30 \mathrm{~cm}$ とし，6 条ドリル播きのトラ クタで作業を行った。

処理区は，2014/15 年では慣行分施区，慣行基肥 2 倍区, 穂肥重点施肥区，穂肥重点 2 倍区を設けた。2015/16 年で は慣行分施区，穂肥重点施肥区，穂肥重点多肥区，堆肥施 用区を設けた。窒素施用量と施肥時期は，第 2 表に示した。

GS は，Zadoks ら（1974）の生育ステージを示す，2014/15 年の慣行分施区では，窒素成分で基肥 $5.5 \mathrm{~g} \mathrm{~m}^{-2}$, 分げつ 肥 $3.0 \mathrm{~g} \mathrm{~m}^{-2}$ (2 月 6 日, GS14), 穂肥 $2.0 \mathrm{~g} \mathrm{~m}^{-2}$ (3 月 16 日, GS32）を尿素で施用した，慣行基肥 2 倍区では，基肥の 窒素施用量を $11.0 \mathrm{~g} \mathrm{~m}^{-2}$ とした。穂肥重点施肥区では，基 肥と分げつ肥を施用せず，茎立ち開始期（2 月 26 日， GS30) に穂肥 I として窒素成分で $5.0 \mathrm{~g} \mathrm{~m}^{-2}$, 止葉抽出期 (4 月 1 日, GS47) に穂肥 II として $5.0 \mathrm{~g} \mathrm{~m}^{-2}$ を尿素で施用した。 穂肥重点 2 倍区は，穂肥 II の窒素施用量を $10.0 \mathrm{~g} \mathrm{~m}^{-2}$ とし た。リンとカリは, 苦土重焼燐 $\left(\mathrm{P}_{2} \mathrm{O}_{5}: 35 \%\right)$ と塩化カリ $\left(\mathrm{K}_{2} \mathrm{O} ： 60 \%\right)$ を用い, 播種直前にリン成分とカリ成分でそ れぞれ $3.6 \mathrm{~g} \mathrm{~m}^{-2}$ ずつ施用した。

2015/16 年の窒素施用量は，慣行分施区では窒素成分で 基肥 $4.0 \mathrm{~g} \mathrm{~m}^{-2}$, 分げつ肥 $3.0 \mathrm{~g} \mathrm{~m}^{-2}$ (1月 21 日, GS14), 穂肥 $3.0 \mathrm{~g} \mathrm{~m}^{-2}$ (3 月 8 日, GS32) を尿素で施用した。穂肥 重点施肥区は, $2014 / 15$ 年と同様に, 穂肥 I に $5.0 \mathrm{~g} \mathrm{~m}^{-2}(2$ 
第 3 表 $2014 / 15$ 年および $2015 / 16$ 年作期の熊本市における旬ごとの日平均気温の平均値 (平均気温), 積算降水量および積算日照時間.

\begin{tabular}{|c|c|c|c|c|c|c|c|c|c|c|c|c|}
\hline \multirow{3}{*}{ 月 } & \multirow{3}{*}{$\begin{array}{c}\text { 旬 } \\
\text { 上旬 }\end{array}$} & \multicolumn{5}{|c|}{$2014 / 15$ 年 } & \multicolumn{6}{|c|}{$2015 / 16$ 年 } \\
\hline & & \multicolumn{2}{|c|}{$\begin{array}{c}\text { 平均気温 } \\
\left({ }^{\circ} \mathrm{C}\right)\end{array}$} & \multicolumn{2}{|c|}{$\begin{array}{c}\text { 降水量 } \\
(\mathrm{mm})\end{array}$} & $\begin{array}{c}\text { 日照時間 } \\
\text { (時間) }\end{array}$ & \multicolumn{2}{|c|}{$\begin{array}{c}\text { 平均気温 } \\
\left({ }^{\circ} \mathrm{C}\right)\end{array}$} & \multicolumn{2}{|c|}{$\begin{array}{c}\text { 降水量 } \\
(\mathrm{mm})\end{array}$} & \multicolumn{2}{|c|}{$\begin{array}{c}\text { 日照時間 } \\
\text { (時間) }\end{array}$} \\
\hline & & 7.1 & $(-2.0)$ & 18.0 & $(-4.1)$ & $32.0 \quad(-18.3)$ & 11.1 & $(+2.0)$ & 60.0 & $(+37.9)$ & 44.8 & $(-5.5)$ \\
\hline \multirow[t]{3}{*}{12} & 中旬 & 5.5 & $(-2.0)$ & 42.5 & $(+27.6)$ & $37.4 \quad(-8.2)$ & 9.3 & $(+1.8)$ & 6.5 & $(-8.4)$ & 54.1 & $(+8.5)$ \\
\hline & 下旬 & 6.2 & $(-0.7)$ & 2.0 & $(-14.6)$ & $58.5 \quad(+6.8)$ & 8.3 & $(+1.4)$ & 25.0 & $(+8.4)$ & 48.4 & $(-3.3)$ \\
\hline & 上旬 & 5.6 & $(-0.5)$ & 8.0 & $(-7.6)$ & $58.6(+14.8)$ & 8.1 & $(+2.0)$ & 11.5 & $(-4.1)$ & 31.0 & $(-12.8)$ \\
\hline \multirow[t]{3}{*}{1} & 中旬 & 6.7 & $(+0.9)$ & 16.5 & $(-8.7)$ & $49.2 \quad(+8.7)$ & 5.2 & $(-0.6)$ & 14.0 & $(-11.2)$ & 26.4 & $(-14.1)$ \\
\hline & 下旬 & 7.4 & $(+2.2)$ & 75.0 & $(+55.7)$ & $35.2(-13.1)$ & 5.0 & $(-0.2)$ & 45.0 & $(+25.7)$ & 25.4 & $(-22.9)$ \\
\hline & 上旬 & 4.5 & $(-1.4)$ & 0.0 & $(-21.7)$ & $47.6 \quad(-2.9)$ & 5.8 & $(-0.1)$ & 0.0 & $(-21.7)$ & 56.8 & $(+6.3)$ \\
\hline \multirow[t]{3}{*}{2} & 中旬 & 7.6 & $(+0.2)$ & 3.5 & $(-29.1)$ & $(+4.1)$ & 8.7 & $(+1.3)$ & 65.5 & $(+32.9)$ & 31.4 & $(-18.1)$ \\
\hline & 下旬 & 8.6 & $(+0.5)$ & 30.0 & $(+1.0)$ & $19.3(-20.3)$ & 7.1 & $(-1.0)$ & 8.5 & $(-20.5)$ & 43.0 & $(+3.4)$ \\
\hline & 上旬 & 7.6 & $(-1 \cdot 1)$ & 58.5 & $(+21.3)$ & $46.4 \quad(-5.7)$ & 12.2 & $(+3.5)$ & 33.0 & $(-4.2)$ & 65.8 & $(+13.7)$ \\
\hline \multirow[t]{3}{*}{3} & 中旬 & 12.2 & $(+1.4)$ & 120.0 & $(+73.4)$ & $(-2.3)$ & 10.8 & $(0.0)$ & 18.0 & $(-28.6)$ & 65.3 & $(+14.2)$ \\
\hline & 下旬 & 12.8 & $(+0.8)$ & 7.5 & $(-46.7)$ & $86.9(+31.9)$ & 11.3 & $(-0.7)$ & 9.0 & $(-45.2)$ & 71.3 & $(+16.3)$ \\
\hline & 上旬 & 17.1 & $(+2.9)$ & 106.5 & $(+52.6)$ & $22.5 \quad(-35.5)$ & 17.0 & $(+2.8)$ & 54.5 & $(+0.6)$ & 30.0 & $(-28.0)$ \\
\hline \multirow[t]{3}{*}{4} & 中旬 & 16.1 & $(+\mathbf{0 . 5})$ & 38.0 & $(-4.8)$ & $39.5(-21.2)$ & 17.2 & $(+1.6)$ & 24.0 & $(-18.8)$ & 71.5 & $(+10.8)$ \\
\hline & 下旬 & 18.3 & $(+0.9)$ & 6.0 & $(-43.2)$ & $82.0(+19.3)$ & 17.5 & $(+\mathbf{0 . 1})$ & 100.0 & $(+50.8)$ & 35.8 & $(-26.9)$ \\
\hline & 上旬 & 20.0 & $(+0.8)$ & 15.0 & $(-59.2)$ & $70.4(+13.1)$ & 19.7 & $(+0.5)$ & 112.5 & $(+38.3)$ & 50.9 & $(-6.4)$ \\
\hline \multirow[t]{2}{*}{5} & 中旬 & 21.1 & $(+1.2)$ & 98.0 & $(+30.2)$ & $50.9(-10.0)$ & 20.9 & $(+1.0)$ & 56.5 & $(-11 \cdot 3)$ & 84.3 & $(+23.4)$ \\
\hline & 下旬 & 22.4 & $(+\mathbf{1 . 1})$ & 18.0 & $(-35.5)$ & $(+9.3)$ & 23.4 & $(+2.1)$ & 104.0 & $(+50.5)$ & 67.4 & $(-1.5)$ \\
\hline
\end{tabular}

表の数值は,気象庁が公開している熊本市の観測データを示す. 括弧内の数值は平年值との差を示す. 太字の值は平年值に比べて高い值を示す.

月 25 日, GS30), 穂肥 I に $5.0 \mathrm{~g} \mathrm{~m}^{-2}$ (4月 1 日, GS47) を 施用した，穂肥重点多肥区は，穂肥 I に $5.0 \mathrm{~g} \mathrm{~m}^{-2}$ ，さらに 3 月 8 日 ( GS32) にも $9.4 \mathrm{~g} \mathrm{~m}^{-2}$, 穂肥 Iに $5.0 \mathrm{~g} \mathrm{~m}^{-2}$ ずつ 施用した，堆肥施用区では, 基肥として牛䨢堆肥 $(\mathrm{N}: 1.2 \%)$ を $1.25 \mathrm{~kg} \mathrm{~m}^{-2}$ 施用し，穂肥 I に窒素成分で $5.0 \mathrm{~g} \mathrm{~m}^{-2}$, 穂 肥Iに $5.0 \mathrm{~g} \mathrm{~m}^{-2}$ ずつ施用した。リンとカリは，前述の苦土 重焼燐と塩化カリをそれぞれ $8.0 \mathrm{~g} \mathrm{~m}^{-2}$ ずつ施用した。

処理区は, 2014/15 年では 3 反復の分割区法, 2015/16 年では 4 反復の分割区法に従って配置した。各処理区の長 さは, 2014/15 年では, 条に沿って $10.0 \mathrm{~m}$, 幅は $1.8 \mathrm{~m}$ （6 条）以上とした. $2015 / 16$ 年では, 条に沿って $7.0 \mathrm{~m}$, 幅 は $1.2 \mathrm{~m}$ (4 条) 以上とした. 2015/16 年に設置した堆肥 施用区は，ブロック 1 とブロック 4 の近傍に配置した。

調査は, 2014/15 年では穂揃い期（2015 年 4 月 15 日） と乳熟期（2015 年 5 月 11 日）拈よび成熟期（2015 年 5 月 31 日）に, $2015 / 16$ 年では止葉抽出期（2016 年 4 月 2 日）, 穂揃い期（2016 年 4 月 17 日），乳熟期（2016 年 5 月 17 日） および成熟期（2016 年 5 月 30 日）に行った。調査内容は, 茎の節位別発生率と発生節位別乾物重および窒素含有率と した。また，穂揃い期では地上部窒素蓄積量，成熟期では 収量, 収量構成要素, 草丈および倒伏程度も調査した。

調査のうち, 発生節位別にみた有効化した茎の発生率, 分げつあたりの器官別乾物重，茥あたりの窒素含有量の調 査については，各プロットから 10 株程度を無作為に抜き 取って供試した，茎の発生率は，まず分げつを主茎から節
位ごとに取り分け, 発生していた分げつの本数を主茥の本 数で除して求めた，発生していた分げつのうち，有効化し ていた分げつは, 穂に粒が 1 粒以上稔実しているものとし, 茎の有効化率を求めた，有効化した茎の発生率は，茎の発 生率と茎の有効化率をかけて求めた，分げつあたりの器官 別乾物重は，茥の発生率を調査したサンプルをさらに器官 別 (穂, 秙, 止葉, 下位葉) に分解し, $70^{\circ} \mathrm{C}$ で 48 時間以上 乾燥させた後測定した. 乾物重を測定したサンプルはミル ミキサーで粉砕し，ケルダール法打よびインドフェノール 法で窒素含有率を求めた。窒素含有量は，器官別乾物重に それぞれの窒素含有率を乗じて求めた。穂揃い期の地上部 窒素蓄積量は, $0.67 \mathrm{~m} \times 0.5 \mathrm{~m}$ の範囲を地際から刈り取り, 器官別に分解して乾物重と窒素含有率を測定し両者を乗じ て求めた。成熟期の地上部窒素蓄積量は, 窒素含有量を求 めた茎（各プロット約 50 本）あたりの窒素含有量に穂数を 乗じて求めた，穂揃い期から成熟期にかけて茎葉から穂に 転流した窒素量は, 穂揃い期における茎葉の窒素蓄積量か ら成熟期に打ける茎葉の窒素蓄積量を引いて求めた。

収量調査の試料は, 3 条を条に沿って $1 \mathrm{~m}$ 地際から刈り 取り, ガラス温室内で風乾させた後, 脱穀, 唐箕選を行っ た，収量は，唐箕選した子実を $2014 / 15$ 年では篩わないま ま, 2015/16 年では篩目 $2.2 \mathrm{~mm}$ で篩った後, 計量し求めた. 全乾物重は収量調查用サンプルで求めた風乾重から水分含 量を差し引いて求めた。穂数もこのサンプルで計算した 千粒重は, 粗収量を調査した子実から無作為に 1000 粒を 
第 4 表 2014/15 年および 2015/16 年の二作期に慣行分施と穂肥重点施肥で栽培した「ミナミノカオリ」の収量, 収量構成要素, 子実夕ンパ ク質含有率 $(\mathrm{GPC})$ および成熟期草丈.

\begin{tabular}{|c|c|c|c|c|c|c|c|c|}
\hline 処理区 & $\begin{array}{c}\text { 収量 } \\
\left(\mathrm{g} \mathrm{m}^{-2}\right)\end{array}$ & $\begin{array}{c}\text { 全乾物重 } \\
\left(\mathrm{g} \mathrm{m}^{-2}\right)\end{array}$ & $\begin{array}{c}\text { 収穫指数 } \\
(\%)\end{array}$ & $\begin{array}{c}\text { 穂数 } \\
\left(\text { 本 } \mathrm{m}^{-2}\right)\end{array}$ & $\begin{array}{c}\text { 一穂粒数 } \\
\text { (粒) }\end{array}$ & $\begin{array}{c}\text { 千粒重 } \\
(\mathrm{g})\end{array}$ & $\begin{array}{l}\text { GPC } \\
(\%)\end{array}$ & $\begin{array}{l}\text { 草丈 } \\
(\mathrm{cm})\end{array}$ \\
\hline \multicolumn{9}{|l|}{$2014 / 15$ 年 } \\
\hline 慣行分施区 & $492^{\mathrm{a}}$ & 1234 & 35.8 & $507^{\mathrm{a}}$ & 26.5 & 37.1 & 8.9 & $90.9^{\mathrm{a}}$ \\
\hline 慣行基肥 2 倍区 & $498^{\mathrm{ac}}$ & 1318 & 33.3 & $565^{a b}$ & 27.3 & 37.5 & 8.6 & $91.2^{\mathrm{a}}$ \\
\hline 穂肥重点施肥区 & $567 \mathrm{~b}$ & 1395 & 35.8 & $605^{\mathrm{b}}$ & 26.8 & 36.7 & 9.1 & $88.7^{\mathrm{b}}$ \\
\hline 穂肥重点 2 倍区 & $558 \mathrm{bc}$ & 1363 & 36.0 & $638^{\mathrm{b}}$ & 29.2 & 36.3 & 10.0 & $88.1^{\mathrm{b}}$ \\
\hline \multicolumn{9}{|l|}{$2015 / 16$ 年 } \\
\hline 慣行分施区 & 582 & 1278 & 39.9 & 531 & 36.7 & 35.6 & $12.5^{\mathrm{a}}$ & 93.4 \\
\hline 穂肥重点施肥区 & 607 & 1312 & 40.5 & 557 & 35.3 & 35.7 & $13.8^{b}$ & 93.0 \\
\hline 穂肥重点多肥区 & 581 & 1288 & 39.4 & 584 & 38.1 & 33.9 & $13.8^{\mathrm{b}}$ & 93.4 \\
\hline
\end{tabular}

収量と千粒重は子実の含水率 $12.5 \%$ に補正した值を示す，英小文字が付された值は分散分析で有意差があることを示し，異なる英小文字は Tukey の有意差検定に执いて 5\%水準で有意差があることを示す.

抽出し計量した，収穫指数は，収量（水分含量を除く）を 全乾物重で除して求めた。一穂粒数は, 収量調査用サンプ ルから無作為に抽出した 20 穂を分解し，その粒数を数え て求めた，子実タンパク質含有率は，子実の窒素含有率に 5.83 を乗じて求めた. 収穫期の草丈は, 茎を各処理区か ら無作為に 20 本選び, 地際から穂の先端（芒を除く）ま での長さを測定した，倒伏程度は，作物調査基準の成長解 析法（広田 2013）に従い，0（無）５（甚）で評価した。

気象データは, 熊本地方気象台の 2014/15年および 2015/16年における旬ごとの值と旬ごとの平年值を使用した.

統計処理は, 2014/15 年が 3 反復の乱塊法, $2015 / 16$ 年 が 4 反復の乱塊法に基づいて, 分散分析した後 Tukey の多 重比較を行い検定した，堆肥施用区の統計処理は, $\mathrm{t}$ 検定 で分析した。

\section{結果}

第 3 表に 2014/15 年および 2015/16 年作期の熊本市にお ける旬ごとの日平均気温の平均值 (平均気温), 積算降水 量および積算日照時間を示した.

$2014 / 15$ 年の 12 月上旬から 2 月下旬では, 平年值に比べ て平均気温は同程度か $0.5 \sim 2.0^{\circ} \mathrm{C}$ 低く, 積算降水量は同 程度で，積算日照時間は $7 \%$ 少なかった. 3 月上旬から 4 月上旬では, 平年值に比べて平均気温は $0.8 \sim 2.9^{\circ} \mathrm{C}$ 高く, 積算降水量は $52 \%$ 多く, 積算日照時間は $5 \%$ 少なかった。 4 月中旬から 5 月下旬では, 平年值に比べて平均気温は 0.5 $\sim 1.2^{\circ} \mathrm{C}$ 高く, 積算降水量は $39 \%$ 少なく, 積算日照時間は 3\%多かった。

$2015 / 16$ 年の 12 月上旬から 2 月下旬では, 平年值に比べ て平均気温は同程度か $1.3 \sim 2.0^{\circ} \mathrm{C}$ 高く, 積算降水量は $17 \%$ 少なく, 積算日照時間は $16 \%$ 少なかった. 3 月上旬か ら 4 月上旬では, 平年值に比べて平均気温は $2.8 \sim 3.5^{\circ} \mathrm{C}$ 高く, 積算降水量は $41 \%$ 少なく, 積算日照時間は $7 \%$ 多かっ た. 4 月中旬から 5 月下旬では, 平年值に比べて平均気温
は $0.1 \sim 2.1^{\circ} \mathrm{C}$ 高く, 積算降水量は $38 \%$ 多く, 積算日照時 間は同程度であった４月中旬から 5 月下旬の積算降水量 は, $2014 / 15$ 年の同じ時期に比べ 2.3 倍多く, 積算日照時 間は $5 \%$ 少なかった。

第 4 表には, 2014/15 年および 2015/16 年の二作期に慣 行分施と穂肥重点施肥で栽培した「ミナミノカオリ」の収 量, 収量構成要素および成熟期の草丈を示した。収穫は, 遠隔地での試験ということもあり, いずれの年次でも慣行 分施区に合わせて行ったが, 穂肥重点施肥区の成熟日は茎 葉の緑度や粒の硬さからみて, 慣行分施区に比べて $2014 / 15$ 年では 4 日, $2015 / 16$ 年では 2 日程度遅れていた。

2014/15 年の収量は, 慣行分施区で $492 \mathrm{~g} \mathrm{~m}^{-2}$, 穂肥重点 施肥区で $567 \mathrm{~g} \mathrm{~m}^{-2}$ と穂肥重点施肥区で有意に高かった。 慣行基肥 2 倍区の収量は $498 \mathrm{~g} \mathrm{~m}^{-2}$ と, 慣行分施区に比べ て増加しなかった，穂肥重点 2 倍区の収量は $558 \mathrm{~g} \mathrm{~m}^{-2}$ と, 穂肥重点施肥に比べて増加しなかった。 2015/16 年の収量 は, 慣行分施区で $582 \mathrm{~g} \mathrm{~m}^{-2}$, 穂肥重点施肥区で $607 \mathrm{~g} \mathrm{~m}^{-2}$, 穂肥重点多肥区で $581 \mathrm{~g} \mathrm{~m}^{-2}$ と処理区間で有意な差はなかっ た。

全乾物重は, 2014/15 年では最も軽かった慣行分施区で $1234 \mathrm{~g} \mathrm{~m}^{-2}$, 最も重かった穂肥重点施肥区で $1395 \mathrm{~g} \mathrm{~m}^{-2}$ で あったが処理区間で有意な差はなかった，2015/16 年では いずれの処理区も $1300 \mathrm{~g} \mathrm{~m}^{-2}$ 程度と有意な差はなかった。

収穫指数は, $2015 / 16$ 年は 2014/15 年に比べて $5 \%$ 程度 高かったが，両年次とも処理による有意な差はなかった．

2014/15 年の穂数は, 慣行分施区で 507 本 $\mathrm{m}^{-2}$, 穂肥重点 施肥区で 605 本 $\mathrm{m}^{-2}$ と穗肥重点施肥区で有意に多かった. 慣行基肥 2 倍区の穂数は 565 本 $\mathrm{m}^{-2}$ で慣行分施区に比べて やや増加したが, 穂肥重点施肥区に比べて少ない傾向があっ た. 穂肥重点 2 倍区の穂数は 638 本 $\mathrm{m}^{-2}$ と穂肥重点施肥区 に比べて有意な差はなかった，2015/16 年は，慣行分施区 で 531 本 $\mathrm{m}^{-2}$, 穂肥重点施肥区で 557 本 $\mathrm{m}^{-2}$, 穂肥重点多肥 区で 584 本 $\mathrm{m}^{-2}$ と，処理区間で有意な差はなかったが，穂 
第 5 表 2015/16 年作期に栽培した「ミナミノカオリ」における発生節位別にみた有効化した茥の発生率.

\begin{tabular}{|c|c|c|c|c|c|}
\hline \multirow{2}{*}{ 処理区 } & \multicolumn{5}{|c|}{ 有効化した茎の発生率（\%） } \\
\hline & 主茎 & 主茎第 1 節 & 主茎第 2 節 & 主茎第 3 節 & 鞘葉節 \\
\hline 慣行施肥区 & $95.7^{\mathrm{a}}(100)$ & $95.7(95.7)$ & $76.6^{\mathrm{a}}(78.7)$ & $19.1^{\mathrm{a}}(21.3)$ & $42.6(53.2)$ \\
\hline 穂肥重点施肥区 & $100.0^{\mathrm{b}} \quad(100)$ & $97.3(97.3)$ & $78.4^{\mathrm{ab}}(78.4)$ & $62.2^{\mathrm{b}} \quad(64.9)$ & $35.1(35.1)$ \\
\hline 穂肥重点多肥区 & $97.3^{\mathrm{ab}}(100)$ & $97.3(97.3)$ & $89.2^{\mathrm{b}} \quad(89.2)$ & $48.6^{\mathrm{c}}(56.8)$ & $40.5(40.5)$ \\
\hline
\end{tabular}

有効化した茎の発生率 $=$ 菱の発生率 $\times$ 菱の有効化率，括弧内の数值は主茎㧍よび分げつの発生率を示す，異なる英小文字は Tukeyの有意差検定において 5\%水準で有意差があることを示す.

第 6 表 2015/16 年作期に基肥として堆肥を施用し, 穂肥重点施肥で栽培した「ミナミノカオリ」の収量, 収量構成要素抒 よび子実タンパク質含有率 (GPC).

\begin{tabular}{lccccccc}
\hline & $\begin{array}{c}\text { 収量 } \\
\left(\mathrm{g} \mathrm{m}^{-2}\right)\end{array}$ & $\begin{array}{c}\text { 全乾物重 } \\
\left(\mathrm{g} \mathrm{m}^{-2}\right)\end{array}$ & $\begin{array}{c}\text { 収穫指数 } \\
(\%)\end{array}$ & $\begin{array}{c}\text { 穂数 } \\
\left(\text { 本 } \mathrm{m}^{-2}\right)\end{array}$ & $\begin{array}{c}\text { 一穂粒数 } \\
(\text { 粒 })\end{array}$ & $\begin{array}{c}\text { 千粒重 } \\
(\mathrm{g})\end{array}$ & $\begin{array}{c}\text { GPC } \\
(\%)\end{array}$ \\
\hline 堆肥施用区 & 643 & 1352 & 41.7 & 555 & 36.8 & 36.7 & 13.4 \\
穂肥重点施肥区との差 & +36 & +40 & +1.2 & -2 & +1.5 & +1.0 & -0.4 \\
有意差 & $\mathrm{ns}$ & $\mathrm{ns}$ & $*$ & $\mathrm{~ns}$ & $\mathrm{~ns}$ & $*$ & $\mathrm{~ns}$ \\
\hline
\end{tabular}

堆肥施用区の収量調査用の個体は，区内の 6 地点から無作為に採取した。*は, 穂肥重点施肥区と比較して $\mathrm{t}$ 検定で $5 \%$ 水 準の有意差があることを示す

肥重点施肥区と穂肥重点多肥区でやや多い傾向があった.

一穂粒数は, 2014/15 年では 26.5〜29.2 粒であったの に対し, 2015/16 年では 35.3〜38.1 粒と, 2015/16 年で 10 粒程度多かった。いずれの年次も穂肥重点施肥区と慣 行分施区との間に有意な差はなかった。

千粒重は, 2014/15 年では $36.3 \mathrm{~g} \sim 37.5 \mathrm{~g}$ であったのに対 し, 2015/16 年では 33.9 35. 6 g と, 2014/15 年が 2015/16 年に比べて $3 \mathrm{~g}$ 程度重かった。 いずれの年次も穂肥重点施 肥区と慣行分施区との間に有意な差はなかった。

2014/15 年の子実タンパク質含有率（GPC）は，処理区 間で差がなかったが，慣行分施区と慣行基肥 2 倍区でそれ ぞれ $8.9 \%$ および $8.6 \%$, 穂肥重点施肥区と穂肥重点 2 倍 区でそれぞれ $9.1 \%$ および $10.0 \%$ と，穂肥重点施肥区で 高い傾向があった。 2015/16 年は，慣行分施区で $12.5 \%$, 穂肥重点施肥区で $13.8 \%$ と，穂肥重点施肥区で有意に高 かった。穂肥重点多肥区の子実タンパク質含有率も, $13.8 \%$ と高かった。

成熟期の草丈は，2014/15 年の穂肥重点施肥区と穂肥重 点 2 倍区では, 茥立ち期前後に窒素施肥量を増加したにも かかわらず，それぞれ $88.7 \mathrm{~cm}, 88.1 \mathrm{~cm}$ と，慣行分施区 や慣行基肥 2 倍区に比べて $2.2 \sim 3.1 \mathrm{~cm}$ 有意に低かった. 2015/16 年の草丈も全ての処理区で約 $93 \mathrm{~cm}$ となり，穂肥 重点施肥区や茎立ち開始期（GS30）と茎立ち期（GS32） に窒素を合わせて $14.6 \mathrm{~g} \mathrm{~m}^{-2}$ 施用した穂肥重点多肥区でも 差がなかった。

いずれの作期も倒伏は発生しておらず，倒伏程度はすべ ての処理区で0 (無) であった.

第 5 表に 2015/16 年作期に栽培した「ミナミノカオリ」 における発生節位別にみた有効化した茎の発生率を示す.
括弧内の数值は成熟期に発生していた茥の発生率を示し, 例えば，慣行分施区の主茥第 2 節の 76.6（78.7）は，成 熟期の時点で主茥第 2 節から発生していた全ての分げつの 発生率が $78.7 \%$ で，それに茥の有効化率をかけて，主茥 第 2 節から発生していた有効分げつの発生率が $76.6 \%$ で あったことを示す。

有効化した茎の発生率は, 主茎では慣行分施区が $95.7 \%$, 穂肥重点多肥区が $97.3 \%$ と一部が無効化してい たが，穂肥重点施肥区では $100 \%$ 有効茎が発生した。主茎 第 1 節分げつでは，いずれの処理区でも有効化した茎の発 生率が $97 \%$ 程度であった。主茥第 2 節分げつでは，慣行 分施区で $76.6 \%$, 穂肥重点施肥区で $78.4 \%$ と同程度で あったのに対し，穂肥重点多肥区では $89.2 \%$ と慣行分施 区に比べて有意に高かった。主茥第 3 節分げつの有効化し た茎の発生率は, 慣行分施区が $19.1 \%$, 穂肥重点施肥区 が $62.2 \%$ と穂肥重点施肥区で有意に高かった。これは, 穂肥重点施肥区では茥の発生率が $64.9 \%$, 慣行分施区 の $21.3 \%$ に比べて高いためであった，穂肥重点多肥区の 主茥第 3 節における有効化した茥の発生率も， $48.6 \%$ と慣 行分施区に比べて有意に高かった。鞘葉節分げつの有効化 した茥の発生率は,いずれの処理区でも $40 \%$ 程度であった。

分げつを発生節位ごとに分類した結果, 主茥第 4 節以上 の節位から発生した 1 次分げつや 1 次分げつから発生した 2 次分げつはほとんどなかった.

第 6 表には, 2015/16 年作期に基肥として堆肥を施用し, 穂肥重点施肥で栽培した「ミナミノカオリ」の収量および 収量構成要素を示した。

堆肥施用区は，全ての収量および収量構成要素が穂肥重 点施肥区と同等かそれ以上となった。収量は穂肥重点施肥 


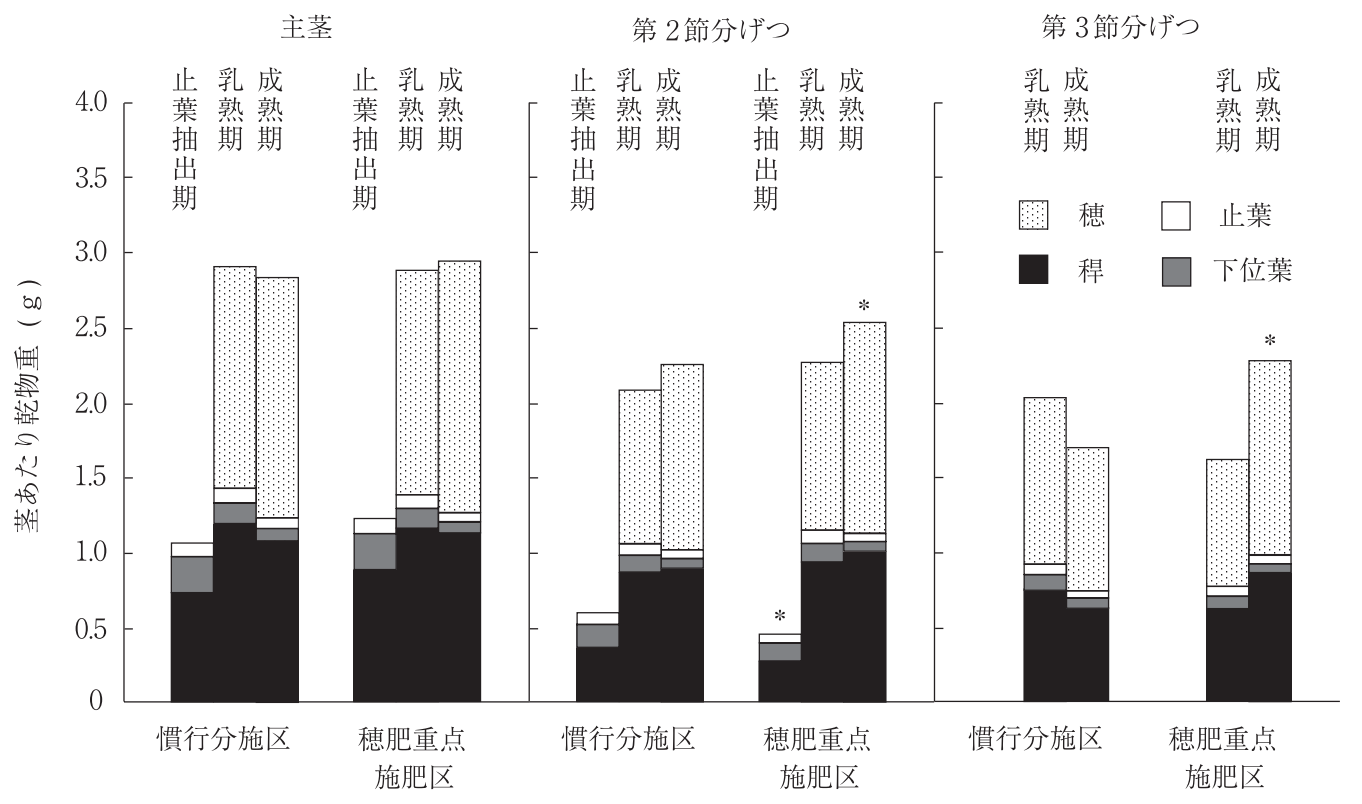

第 1 図 2015/16 年作期に栽培した「ミナミノカオリ」における主茎，第 2 節分げつおよび第 3 節分げつあた りの器官別乾物重.

*は，茎全体の乾物重が同じ生育ステージの慣行分施区に対して 5\%水準で有意差があることを示す.

区に比べて 6\%程度高かった. 穂数は穂肥重点施肥区に比 べて有意な差がなかった，収穫指数と千粒重は穂肥重点施 肥区に比べて有意に高かった。 子実タンパク質含有率は穂 肥重点施肥に比べて $0.4 \%$ 低かった.

第 1 図に 2015/16 年作期に栽培した「ミナミノカオリ」 に扔ける主茥，第 2 節分げつおよび第 3 節分げつあたりの 器官別乾物重を示した.

主茎全体の乾物重は, 慣行分施区と穂肥重点施肥区のい ずれも止葉抽出期で $1.1 \mathrm{~g}$, 乳熟期で $2.9 \mathrm{~g}$ と同程度であっ た. 乳熟期から成熟期にかけては, 穂肥重点施肥区が 0.05 $\mathrm{g}$ 増加したのに対し, 慣行分施区では $0.05 \mathrm{~g}$ 減少したが, 成熟期における茎全体の乾物重は, 慣行分施区で $2.83 \mathrm{~g}$, 穂肥重点施肥区で $2.93 \mathrm{~g}$ と同程度であった。

第 2 節分げつ全体の乾物重は, 止葉抽出期では慣行分施 区が穂肥重点施肥区に比べて有意に重かった。止葉抽出期 から乳熟期にかけては, 穂肥重点施肥区では各器官の乾物 増加量が慣行分施区に比べて 9 17\%多く, 茥全体の乾物 増加量が $1.66 \mathrm{~g}$ と慣行分施区の $1.48 \mathrm{~g}$ を上回った。 その 結果, 乳熟期に扔ける茎全体の乾物重は, 穂肥重点施肥区 では慣行分施区に比べて $0.21 \mathrm{~g}$ 程度重い傾向があった。 乳熟期から成熟期にかけての増加量も, 慣行分施区で 0.15 $\mathrm{g}$ であったのに対し, 穂肥重点施肥区では $0.27 \mathrm{~g}$ と穂肥重 点施肥区で多く, 成熟期に扔ける茎全体の乾物重が慣行分 施区で $2.24 \mathrm{~g}$, 穂肥重点施肥区で $2.53 \mathrm{~g}$ と, 穂肥重点施 肥区が慣行分施区に比べて有意に重かった。

第 3 節分げつ全体の乾物重は, 止葉抽出期では分げつが 葉腋から抽出していなかったため, 測定しなかった。乳熟 期における茎全体の乾物重は, 慣行分施区が $2.03 \mathrm{~g}$ であっ
たのに対し，穂肥重点施肥区で $1.61 \mathrm{~g}$ と，慣行分施区が 穂肥重点施肥区に比べて重い傾向があった，乳熟期から成 熟期にかけては, 慣行分施区が $0.36 \mathrm{~g}$ 減少したのに対し, 穂肥重点施肥区は $0.67 \mathrm{~g}$ 増加した。 これは, 慣行分施区 では無効化した茎の割合が多く，穂や稈，葉のいずれも乾 物重が減少したためであった。その結果，成熟期における 茎全体の乾物重は, 慣行分施区で $1.67 \mathrm{~g}$, 穂肥重点施肥区 で $2.28 \mathrm{~g}$ と穂肥重点施肥区が慣行分施区に比べて有意に 重かった。

第 2 図に, 2015/16 年作期に栽培した「ミナミノカオリ」 に扔ける主茎, 第 2 節分げつおよび第 3 節分げつあたりの 器官別窒素含有量および窒素含有率を示した.

主茎全体の窒素含有量は，慣行分施区と穂肥重点施肥区 のいずれも止葉抽出期では $18 \mathrm{mg}$, 乳熟期では $34 \mathrm{mg}$ であっ た. 乳熟期から成熟期にかけては, 穂肥重点施肥区では主 茎全体の窒素含有量が $3.2 \mathrm{mg}$ 増加したのに対し, 慣行分 施区では $0.9 \mathrm{mg}$ 減少した。成熟期では, 穂肥重点施肥区 における穂の窒素含有量が $31.5 \mathrm{mg}$ と慣行分施区の 27.8 $\mathrm{mg}$ に比べて有意に多くなり, 主茎全体の窒素含有量が慣 行分施区に比べて有意に多くなった。

第 2 節分げつ全体の窒素含有量は, 止葉抽出期では慣行 分施区で $11.9 \mathrm{mg}$, 穂肥重点施肥区で $8.2 \mathrm{mg}$ と, 穂肥重 点施肥区に比べて慣行分施区で多い傾向があった．これは, 慣行分施区の窒素含有量がどの器官においても, 穂肥重点 施肥区に比べて 35〜 56\%多いためであった，乳熟期の茎全 体の窒素含有量は, 慣行分施区と穂肥重点施肥区のいずれ も $28 \mathrm{mg}$ であった，乳熟期から成熟期にかけては，慣行分 施区が $0.3 \mathrm{mg}$ しか増加しなかったのに対し, 穂肥重点施 


\begin{tabular}{llll}
\multicolumn{2}{c}{ 主茥 } & \multicolumn{2}{c}{ 第2節分げつ } \\
止乳成 & 止乳成 & 止乳成 & 步乳成 \\
葉熟 & 葉 熟熟 & 葉熟熟 & 葉熟 \\
抽期 & 抽期期 & 抽期期 & 抽期 \\
出 & 出 & 岃 & 出 \\
期 & 期 & 期 & 期
\end{tabular}

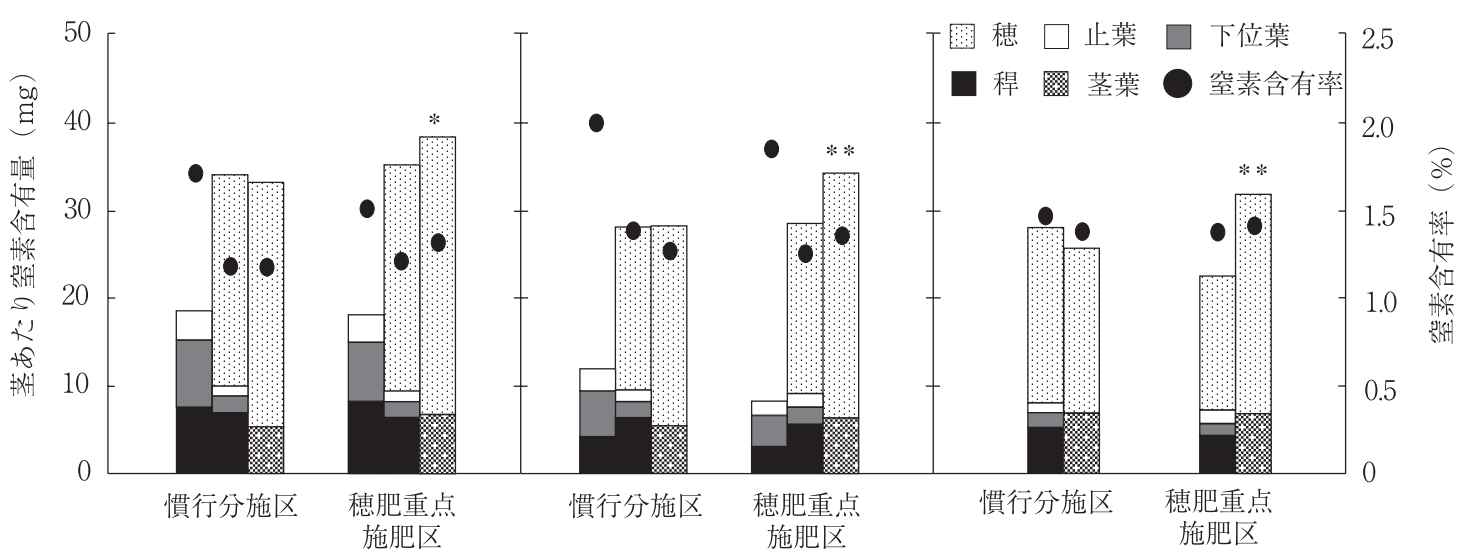

第 2 図 2015/16 年作期に栽培した「ミナミノカオリ」における主茥, 第 2 節分げつおよび第 3 節分げつあたりの器官別 窒素含有量㧍よび窒素含有率.

成熟期は葉身と稈を一括して茥葉として測定した。，**は，茥全体の窒素含有量が同じ生育ステージの慣行分施 区に対してそれぞれ $5 \%, 1 \%$ 水準で有意差があることを示す。

肥区では $5.8 \mathrm{mg}$ 増加した。成熟期では, 主茎と同様に穂 肥重点施肥区の穂の窒素含有量が慣行分施区に比べて有意 に多く, 茎全体の窒素含有量も $34.2 \mathrm{mg}$ と慣行分施区の $28.2 \mathrm{mg}$ に比べて有意に多くなった.

第 3 節分げつ全体の窒素含有量は, 乳熟期では穂の窒素 含有量が多かったため, 慣行分施区で $27.9 \mathrm{mg}$ と, 穂肥 重点施肥区の $22.0 \mathrm{mg}$ に比べて多い傾向があった，乳熟 期から成熟期にかけては，慣行分施区で $5.0 \mathrm{mg}$ 減少した のに対し, 穂肥重点施肥区では $9.8 \mathrm{mg}$ 増加した. その結果, 成熟期の茎全体の窒素含有量は，慣行分施区で $22.9 \mathrm{mg}$, 穂肥重点施肥区で $31.8 \mathrm{mg}$ と穂肥重点施肥区で有意に多 くなった。成熟期の穂の窒素含有量も，慣行分施区が $18.7 \mathrm{mg}$, 穂肥重点施肥区が $24.9 \mathrm{mg}$ と, 穂肥重点施肥区 で有意に多かった。

茎全体の窒素含有率は，慣行分施区では主荎やいずれの 分げつでも止葉抽出期から成熟期にかけて低下したのに対 し，穂肥重点施肥区では乳熟期から成熟期にかけて低下し なかった。

第 3 図に 2015/16 年作期に栽培した「ミナミノカオリ」 における穂揃い期および成熟期の地上部窒素蓄積量を示し た，穂揃い期に抢ける地上部全体の窒素蓄積量は，慣行分 施区で $12.0 \mathrm{~g} \mathrm{~m}^{-2}$, 穂肥重点施肥区で $13.5 \mathrm{~g} \mathrm{~m}^{-2}$ と穂肥重 点施肥区でやや多い傾向があった，穂揃い期から成熟期に かけては，慣行分施区で $3.6 \mathrm{~g} \mathrm{~m}^{-2}$ 増加したのに対し，穂肥 重点施肥区では $5.3 \mathrm{~g} \mathrm{~m}^{-2}$ 増加した。 また，穂揃い期から成 熟期にかけて茎葉から穂に転流した窒素量は，慣行分施区 で $6.0 \mathrm{~g} \mathrm{~m}^{-2}$, 穂肥重点施肥区で $6.8 \mathrm{~g} \mathrm{~m}^{-2}$ と穗肥重点施肥 区でわずかに多かった，成熟期では，穂の窒素蓄積量と茎

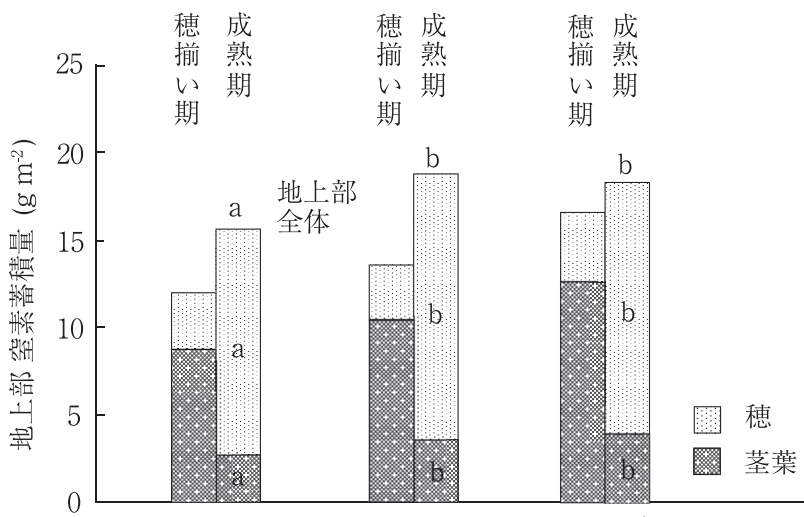

慣行分施区 穂肥重点施肥区 穂肥重点多肥区

第 3 図 2015/16 年作期に栽培した「ミナミノカオリ」における穂 揃期および成熟期の地上部窒素蓄積量.

測定したブロック数は, 穂揃期の慣行分施区では 2 ブロック, それ以外は 4 ブロックとした. 異なる英小文字は, 地上部全体, 穂，茎葉ごとに5\%水準で有意差があることを示す．

葉の窒素蓄積量のいずれも穂肥重点施肥区で有意に多く, 地上部全体の窒素蓄積量が慣行分施区で $15.6 \mathrm{~g} \mathrm{~m}^{-2}$, 穂肥 重点施肥区で $18.8 \mathrm{~g} \mathrm{~m}^{-2}$ と穂肥重点施肥区で有意に多かっ た.

穂肥重点多肥区は，穂揃い期では地上部全体の窒素蓄積 量が $16.6 \mathrm{~g} \mathrm{~m}^{-2}$ と慣行分施区や穂肥重点施肥区に比べて多 い傾向であった，しかし，穂揃い期から成熟期にかけて吸 収した窒素量が $1.8 \mathrm{~g} \mathrm{~m}^{-2}$ と少なく, 成熟期の窒素蓄積量 が $18.4 \mathrm{~g} \mathrm{~m}^{-2}$ と穂肥重点施肥区と同程度にとどまった。 


\section{考察}

本研究では, 2014/15 年および 2015/16 年作期に, 熊本 県におけるコムギの多収地域において, 従来の施肥方法で 重視される基肥と分げつ肥の窒素施肥を行わず，その分穂 肥を増肥する穂肥重点施肥の効果を検証した。

穂肥重点施肥区の収量は, 慣行分施区に比べて 2014/15 年の試験では増加し, $2015 / 16$ 年の試験でも同じ水準となっ た. 穂肥重点施肥区の収量が高くなった原因は, 慣行分施 区に比べて穂数が増加したためであった（第 4 表）、コム ギの収量は穂数と比例することが多く（稲村ら 2007）, こ れまでの施肥法では分げつの発生を促す基肥と分げつ肥 (和田 2002）が重要視されてきた。本研究では, 穂肥重点 施肥区で穂数が増加した原因は，有効化する茥の割合が高 くなるためと考え, 発生節位ごとに有効化した茥の発生率 を調査した，その結果，穂肥重点施肥区の有効化した茎の 発生率は, 主茥, 主茥第 1 節分げつ, 主茥第 2 節分げつは 慣行分施区と違いがないものの, 主茥第 3 節分げつは慣行 分施区に比べて有意に高かった(第 5 表)。これまでの研 究でも, 穂数は穂肥を増肥することで増加し, その結果収 量が高くなることが報告されている（江口ら 1969, 倉井ら 1998, 竹内ら 2006, 土谷 2012 , 渡邊ら 2016). 穂肥重点施 肥は，発生した分げつの中でもとくに主茥第 3 節分げつの ような主茥高位節から発生した茎の無効化を防ぐ効果があ り，穂数を従来の分施体系よりも多くすることが可能であ ることが明らかとなった。

麦類では, 茥立ち後に窒素追肥量を増やすことにより遅 れ穂が増加することが報告されている（倉井ら 1998）。本 研究の穂肥重点施肥区では, 最も発生時期が遅かった主茥 第 3 節分げつが止葉抽出期以降に発生したが，成熟期では 第 2 節分げつと同程度の乾物重にまで成長した (第 1 図). 穂肥重点施肥区の主茎第 3 節分げつの千粒重は $37.7 \mathrm{~g}$ と, 主茥や他の分げつの $36.6 \mathrm{~g}$ と同程度であった（デー夕省 略). 渡邊ら（2016）は, 基肥は無効分げつの発生を促し, 有効茥歩合を低下させることを報告している。鎌田ら （2016a）は裸麦において，穂肥を増肥すると本来無効化す る軽い茥が遅れ穂や比較的重い無効茥になることを明らか にした.このことから, 倉井ら（1998）の報告のように穂 肥の窒素増肥が遅れ穂を増加させる原因のひとつは, 基肥 や分げつ肥を施用したことによって，軽い茥が多く発生す るためと考えられた。浦野 (2014) が試験したオオムギの 後期重点施肥法でも, 本研究と同様に (第 5 表), 基肥と 分げつ肥を省略すると無効化する茥がほとんど発生しな かった，以上のことから，基肥と分げつ肥を省略した穂肥 重点施肥は, 軽い茥の発生を抑えることにより遅れ穂の発 生を抑えると考えられた。

一穂粒数は, 穂肥窒素を増肥しても増加しなかった（第 4 表)。一穂粒数は, 窒素の施肥も含め, 様々な要因で増減す ることが知られているが（藤吉 1953 , 佐藤ら 1993, 福嶌ら
2004, 豊田ら 2004, 荻内 - 作山 2005, 高橋ら 2010, Zheng ら 2014, Guo and Schnurbusch 2015），倉井ら（1998）は，茥 立ち後の窒素追肥は一穂粒数を増加させ収量を高くしたと 報告している。本研究では, 一穂粒数は, 茥立ち後にあた る止葉抽出期に窒素を穂肥重点施肥区で $5 \mathrm{~g} \mathrm{~m}^{-2}$, 穂肥重点 2 倍区で $10 \mathrm{~g} \mathrm{~m}^{-2}$ 施肥したにもかかわらず，増加しなかっ た (第 4 表)。また, 千粒重も, 穂肥窒素を増肥しても増 加しなかった (第 4 表). 渡邊ら（2016）は, 日本めん用 品種「さとのそら」において, 生育後期重点施肥で栽培す ることで登熟後半まで乾物生産が高く, 一穂粒数と千粒重 が増加したことを報告している，渡邊ら（2016）の結果と 本研究とではこの点が明らかに異なっている.コムギでは, 施肥窒素量が収量構成要素におよぼす影響は品種によって 異なる (Noureldin ら 2013) ため,「ミナミノカオリ」と「さ とのそら」では穂肥重点施肥が穂数や一穂粒数, 千粒重に およぼす影響が異なると考えられた。

穂肥重点施肥区の収量は, 2014/15 年では慣行分施区に 比べて 15\%増加したが，2015/16 年では慣行分施区に比べ て増収効果は小さかった (第 4 表)。コムギの収量は, 登 熟期間の降水量と負の相関があることが報告されている (松江ら 2001). 生育後期重点施肥は, 登熟期間の乾物生産 を高く維持することで収量が増加する（渡邊ら 2016）ため, 登熟期間の気象が収量に強く影響すると考えられる。 $2015 / 16$ 年は登熟期間（4月中旬から 5 月下旬）の積算降 水量が 2014/15 年に比べて 2.3 倍多かった (第 3 表).こ のような多雨条件により, 2015/16 年の収量は, 穂肥重点 施肥区でも慣行分施区と同程度になったと考えられた。

穂肥重点施肥区では，収量が慣行分施区と同水準の場合 (2015/16 年) には子実タンパク質含有率が高く, 収量が高 くなった場合（2014/15 年）でも子実タンパク質含有率が 低下しなかった (第 4 表).コムギの子実タンパク質含有 率は収量の増加に伴って低下することが報告されている (江口ら 1969, 岩渕ら 2011). 本研究では, 穂肥重点施肥 区は慣行分施区に比べて穂揃い期から成熟期にかけて吸収 した窒素の量が $1.7 \mathrm{~g} \mathrm{~m}^{-2}$ 多くなった (第 3 図). 子実タン パク質含有率は，登熟期間中の窒素吸収量を増やす穂揃い 期から開花期にかけての窒素施肥（Rawluk ら 2000, 高山 ら 2004, 岩渕ら 2007, 島崎ら 2014, 石丸ら 2015), 開花 後における根に蓄積した窒素の再転流 (Anderssonら 2005), 地力に由来する窒素の吸収（石丸ら 2016）が重要 であることが報告されている。本研究で設定した穂肥重点 施肥は, 慣行の分施体系に比べて穂揃い期以降の窒素吸収 量を増やすことから, 多収化しても子実タンパク質含有率 を高い水準に維持できると考えられた。一方, 穂肥重点施 肥区は穂揃い期から成熟期にかけて茥葉から穂に転流した 窒素量が慣行分施区に比べて $0.8 \mathrm{~g} \mathrm{~m}^{-2}$ 多かったものの, 茥葉に残った窒素量も多かった (第 3 図). 栽培を行った 試験圃が遠地であることから，いずれの作期でも穂肥重点 施肥区は慣行分施区の成熟期に合わせて収穫したため, や 
や早刚りすることとなった，収穫を適期に行えば，茎葉か ら穂への窒素再転流量をさらに増加できる可能性もあると 考えられた。

2014/15 年の子実タンパク質含有率は，いずれの処理区 においても2015/16 年に比べて低かった（第 4 表）。鎌田 ら（2016b）は裸麦において，穂あたりの子実窒素含有量 と子実乾物重を報告している。このデータから子実窒素含 有率を再計算すると，子実窒素含有率は成熟約 10 日前か ら成熟期にかけて約 $1.2 \%$ から約 $1.6 \%$ に増加していた。 2014/15 年で子実タンパク質含有率が低かった原因は, 収 穫が適期よりも早く, 子実の窒素含有率が増加する前に収 穫したためと考えられた。

穂肥重点施肥区は，慣行分施区に比べて成熟期の草丈が 短かった (第 4 表)。これまでの研究では, 茎立ち前から 茎立ち期にかけての追肥は程長を伸ばし，倒伏の危険性を 高めることが報告されている（江口ら 1969, 倉井ら 1998, 土谷 2012）。これらの報告は，いずれも基肥や分げつ肥を 重視して窒素施用する従来型の施肥体系にさらに穂肥を増 肥する条件で試験されたものである，倒伏と穂肥施肥量の 関係は，穂肥以前の窒素施用量とも密接に関係する可能性 が高く，その点をさらに検証する必要があると考えられた。

本研究では, 基肥や穂肥の窒素施肥量を増やしても収量 は増加しなかった（第 4 表）. Hitz ら（2017）は，収量と 成熟期の地上部窒素蓄積量に強い正の相関があることを報 告している. 穂肥重点多肥区は穂肥窒素を $9.4 \mathrm{~g} \mathrm{~m}^{-2}$ 増肥 したにもかかわらず，成熟期の地上部窒素蓄積量が穂肥重 点施肥区に比べて増加しなかったため(第 3 図), 収量も 増加しなかったと考えられた。

基肥に堆肥を施用した堆肥施用区では，穂肥重点施肥区 に比べて増収傾向があった（第 6 表）。堆肥施用区では, とくに千粒重が有意に高くなることから (第 6 表)，地力 を高めることでさらに登熟期の物質生産が高まる可能性が 示唆された. 石丸ら（2016）は, 安定同位体を用いた解析 により，中華めん用品種「ちくしW2 号」の子実窒素は 41 〜 49\%が地力窒素に由来することを明らかにしている，穂 肥重点施肥によるさらなる多収化を図るためには，化学肥 料の多投入に頼らず，地力を高めることも重要であると考 えられた

謝辞：栽培試験の遂行にあたり,JA 菊池の皆様，熊本県 農業研究センターの坂梨二郎氏，圃場耕作者の皆様にご協 力いただいた。ここに記して感謝申し上げます，本研究は， 農林水産省委託プロジェクト「生産現場強化のための研究 開発 - 多収阻害要因の診断法及び対策技術の開発」および JSPS 科研費 JP26450021 の助成により実施いたしました。

\section{引用文献}

AHDB. 2009. 冬小麦経営指針. https://cereals.ahdb.org.uk/media/180204/ g48-nitrogen-for-winter-wheat-management-guidelines.pdf (2017/ $1 / 23$ 閲覧).
Andersson, A., Johansson, E. and Oscarson, P. 2005. Nitrogen redistribution from the roots in post-anthesis plants of spring wheat. Plant Soil 269: 321-332.

江口久夫・平野寿助・吉田博哉 1969. 暖地におけるコムギの良質化 栽培に関する研究 (第 2 報) 3 要素施用量および窒素の施用時期 · 施用法と品質との関係. 中国農試研報 A17: 81-111.

藤田雅也·河田尚之. 関昌子.八田浩一 波多野哲也 - 田谷省三 ·佐々 木昭博 $\cdot$ 氏原和人 · 谷口義則 ·平将人 · 塔野岡卓司 · 堤忠宏 $\cdot$ 坂 智広 2009. 製パン適性の良い硬質小麦新品種「ミナミノカオリ」 の育成. 九州沖縄農研報告 51: 41-64.

藤吉正記 1953. 小麦と裸麦に於ける秋播性程度及び播種期と生育- 収 量との関係について. 九州農試彙報 1: 375-406.

福嶌陽・楠田宰・古畑昌巳 2004. 播種量および施肥法がコムギ品種「チ クゴイズミ」の稈長・収量・原麦の蛋白質含量に及ぼす影響. 日 作九支報 70: 23-25.

Guo, Z. and Schnurbusch, T. 2015. Variation of floret fertility in hexaploidy wheat revealed by tiller removal. J Exp. Bot. 66: 59455948.

広田雄二 2013. 日本作物学会九州支部会編, 作物調査基準 初版第1刷. 日本作物学会九州支部. 10.

Hitz, K., Clark, A.J. and Sanford, D.A.V. 2017. Identifying nitrogen-use efficient soft red winter wheat lines in high and low nitrogen environments. Field Crops Res. 200: 1-9.

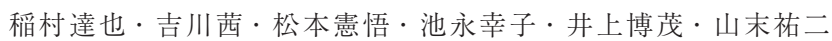
2007. コムギ収量の圃場内変動をもたらす要因の解析と可変量管 理の可能性. 日作紀 76: 189-197.

石丸知道・荒木雅登・荒木卓哉・山本富三 2015. 適正子実タンパク 質含有率からみた中華めん用コムギ品種「ちくし W2 号」の穂揃 期後の窒素追肥時期. 日作紀 84: 155-161.

石丸知道・荒木雅登・荒木卓哉・山本富三 2016. 中華めん用コムギ 品種「ちくし W2 号」の子実タンパク質含有量における施肥窒素 の利用率と地力窒素の寄与率. 日作紀 85: 385-390.

岩㴊哲也 - 田中浩平 · 松江勇次 - 松中仁 - 山口未次 2007. 開花期の 窒素追肥がパン用コムギ品種「ミナミノカオリ」と「ニシノカオリ」 の製粉性, 生地の物性㧍よび製パン適性に及ぼす影響. 日作紀 76: 37-44.

岩㴊哲也 ·浜地勇次 - 宮崎真行 - 内川修 2011. 近年の北部九州産コ ムギにおける子実タンパク質含有率低下の要因解析. 日作紀 80: 59-64.

鎌田英一郎 · 高橋肇 - 池尻明彦 - 内山亜希 - 金子和彦 ·松永雅志 · 内田早耶香 · 荒木英樹 · 丹野研一 2016a. 穂肥窒素の増施および重 点化による後期重点型施肥栽培が裸麦の分げつの有効化に及ぼす 影響. 日作紀 85: 16-22.

鎌田英一郎 · 高橋肇 - 池尻明彦 - 内山亜希 - 金子和彦 ·松永雅志 · 荒木英樹 · 丹野研一 2016b. 穂肥窒素の増施が裸麦の登熟期間中の 物質生産求よび窒素代謝に及ぼす影響. 日作紀 85: 288-293.

倉井耕一 · 木村守 ·遠山明子 1998. 小麦の追肥による生育パターン の変化と追肥技術への応用. 栃木農試研報 47: 1-12.

松江勇次 ·陣内暢明 - 馬場孝秀 - 岩㴊哲也 - 福島裕助 ·古庄雅彦 2001. 1999年における北部九州産麦類の多収要因の解析. 日作紀 70: 261266.

Noureldin, N.A., Saudy, H.S., Ashmawy, F. and Saed, H.M. 2013. Grain yield response index of bread wheat cultivars as influenced by nitrogen levels. Annals Agric. Sci. 58: 147-152. 
農林水産省 2017a. 麦類の農産物検査結果. http://www.maff.go.jp/j/seisan/ syoryu/kensa/mugi/index.html (2017/1/23 閲覧).

農林水産省 2017b. 作物統計の作況調査「市町村別データ」. http://www. maff.go.jp/j/tokei/kouhyou/sakumotu/sakkyou_kome/index.html (2017/1/23 閲覧).

荻内謙吾 ·作山一夫 2005. 秋播性コムギの冬季播種栽培における好 適窒素施肥法. 日作紀 74: 17-22.

Rawluk, C.D.L., Racz, G.J. and Grant, C.A. 2000. Uptake of foliar or soil application of $15 \mathrm{~N}$-labelled urea solution at anthesis and its affect on wheat grain yield and protein. Can. J. Plant Sci. 80: 331-334.

佐藤暁子. 末永一博 $\cdot 川 \square$ 藪美 1993. コムギの穂数及び穂の諸形質 に及ぼす時期別遮光処理の影響. 日作紀 62: 206-210.

佐藤暁子・ 小綿美環子・ 中村信吾 - 渡辺満 1999. コムギの製パン適 性に及ぼす窒素追肥時期の影響. 日作紀 68: 217-223.

佐藤三佳子 ·五十嵐俊成 · 櫻井道彦 · 鈴木和織 · 柳原哲司 - 奥村正 敏 2009. 北海道北部地域に抢ける春まきコムギ「春よ恋」に対す る開花期以降の尿素葉面散布が子実タンパク質含有率と収量に及 ぼす効果およびその変動要因. 日作紀 78: 9-16.

関根久子・梅本雅 2015. 小麦収量水準格差の形成要因 - 日本とドイ ツの比較分析 - . 中央農研研報 24: 31-54.

島崎由美・渡邊好昭・松山宏美 ·平沢正 2014. 窒素追肥の時期がコ ムギ品種「ユメシホウ」の収量および子実タンパク質含有率に及 ぼす影響. 日作紀 83: 25-31.

島崎由美 · 赤坂舞子 · 渡邊好昭 · 大下泰生 · 松山宏美 - 平沢正 2015 . コムギの開花期地上部窒素蓄積量は子実タンパク質含有率と開花 期窒素追肥の子実タンパク質含有率向上効果に影響する. 日作紀 84: 140-149.

高橋肇・張立 · 松澤智彦 · 藤本香奈 · 山口真司 $\cdot$ Md. Alamgir Hossain ·
荒木英樹 2010. 山口県で早播栽培した秋播性程度が III〜V のコム ギ品種の収量性に対する幼穂形成期間における窒素追肥処理の効 果. 日作紀 79: 468-475.

高山敏之・長嶺敬・石川直幸・田谷省三 2004. コムギにおける出穂 10日後追肥の効果. 日作紀 73: 157-162.

竹内実 · 近乗偉夫 ·吉良知彦 2006. 榇油醉造用硬質コムギの高夕ン パク質化へ向けた施肥法について. 日作九支報 72: 25-28.

豊田正範 · 小林洋介 · 三好祐介 · 安村直子 - 楠谷彰人 · 浅沼興一郎 2004. 播種期によるコムギ主茎の葉, 小穂および小花の分化数成立 過程の変異. 日作紀 73: 10-17.

土谷大輔 2012. 硬質小麦品種「ミナミノカオリ」の収量向上および 子実タンパク質含有率制御技術. 長崎農林技七研報 3: 13-26.

浦野光一郎 - 保科亨 2012 . 肥効調節型肥料の全量基肥播種溝施用が 小麦の生育, 収量および品質に及ぼす影響. 日作紀 81(別 2): 202203.

浦野光一郎 2014. 硫安の全量 3 月上旬施肥が六条大麦の生育, 収量お よび品質に及ぼす影響. 日作中国支研集 54: 29-30.

渡邊和洋 - 中園江 - 中村大輔 - 西谷友寛 - 西村奈月 - 松島弘明 - 谷 尾昌彦・江原宏 2016. 生育後期重点施肥がコムギの生育と収量に 及ぼす影響. 日作紀 85: 373-384.

和田道弘 2002. 日本作物学会編, 作物学辞典 初版第 1 刷. 朝倉書店, 東京. 339 .

Zadoks, C.J., Chang, T.T. and Konzak, F.C. 1974. A decimal code for the growth stages of cereals. Weed Res. 14: 415-421.

Zheng, C., Zhu, Y., Zhu, H., Kang, G., Guo, T. and Wang C. 2014. Floret development and grain setting characteristics in winter wheat in response to pre-anthesis application of 6-benzylaminopurine. Field Crops Res. 169: 70-76.

Effect of Intensive Nitrogen Fertilization During Stem Elongation (INFSE) on Grain Yield and Grain Protein Content in a Bread Wheat Cultivar "Minaminokaori" : Keisuke Mizuta", Hideki Araki ${ }^{1)}$, Kazuhiro NAKAmura", Hitoshi MatsunaKa", Ken-ichi TANno ${ }^{2)}$ and Tadashi TaKahashi ${ }^{1)}\left({ }^{1)}\right.$ Grad. Sch. of Tech. for Innov., Yamaguchi Univ., Yamaguchi 753-8515; Japan; ${ }^{2)}$ Natl. Agric. Res. Cent. For Kyushu Okinawa Region.)

Abstract : "Minaminokaori", a wheat cultivar for bread making in western Japan, produces protein-rich grains although its yield is moderately low. The objective of this study was to examine the effects of intensive nitrogen fertilization during stem elongation (INFSE), but no nitrogen fertilization during vegetative stages, on grain protein content (GPC) and grain yield in $2014 / 15$ and 2015 / 16 in Kumamoto prefecture. In both years, spike number per unit area in INFSE-treated plants was 5-20\% larger than that in conventionally fertilized plants (control). In 2014/15, grain yield of INFSE was $15 \%$ higher than in the control while GPC was not reduced. In $2015 / 16$, although the grain yield in INFSE was identical $\left(607 \mathrm{~g} \mathrm{~m}^{-2}\right)$ to the control, GPC was significantly high (13.8\%) compared with the control (12.5\%). The number of grains per spike and 1000 grain weight were not influenced by INFSE in both years. The increase in spike number was attributed to the increased number of spike-bearing tillers at higher nodes of the main stem. For instance, $62.2 \%$ of the third nodes on the main stem bore productive spikes in INFSEtreated plants, but only $19.1 \%$ in the control. The mean dry weight of tillers from the third nodes was $2.28 \mathrm{~g}$ in INFSE-treated plants and $1.67 \mathrm{~g}$ in the control. The aboveground part of the INFSE-treated plants accumulated more nitrogen $\left(5.3 \mathrm{~g} \mathrm{~m}^{-2}\right)$ than the control $\left(3.6 \mathrm{~g} \mathrm{~m}^{-2}\right)$ during full heading to maturity. Therefore, total nitrogen accumulation was significantly higher in the INFSE-treated plants $\left(18.8 \mathrm{~g} \mathrm{~m}^{-2}\right)$ than in the control $\left(15.6 \mathrm{~g} \mathrm{~m}^{-2}\right)$. INFSE can increase yield and GPC by increasing the uptake of nitrogen, and thus this fertilization system is suitable for cultivation of bread wheat cultivars.

Key words : Grain protein content, High yield, Intensive nitrogen fertilization during stem elongation (INFSE), Minaminokaori, Nitrogen accumulation, Tiller, Wheat cultivar for bread-making. 